Bangladesh J. Bot. 39(1): 57-60, 2010 (June)

\title{
EFFECTS OF PHOSPHORUS DEFICIENCY ON ANATOMICAL STRUCTURES IN MAIZE (ZEA MAYS L.)
}

\author{
Bimal Chandra Sarker ${ }^{1}$, J. L. Karmoker and Parveen Rashid \\ Department of Botany, University of Dhaka, Dhaka-1000, Bangladesh
}

Key words: Phosphorus deficiency, Anatomy, Maize, Zea mays L.

\begin{abstract}
Anatomical response of maize (Zea mays L.) to phosphorus deficiency grown in sand culture and half strength Hoagland solution revealed that phosphorus deficiency caused a decrease in diameter of the root and stem as well as thickness of the leaf. Epidermal cells of the root, stem and leaf became thickened, cortical zone of root and stem was reduced, endodermal and pericycle cells became smaller and thick walled in phosphorus deficient plants. The prominent structural changes due to phosphorus deficiency occurred in the vascular system where the vascular area is decreased with less number of xylem vessels and smaller size of the cavity. Phosphorus deficiency also resulted in decreased number and smaller sized stomata in leaves.
\end{abstract}

\section{Introduction}

Plants respond to various stresses through morphological, anatomical and physiological adjustments. Although essential for plant growth and development, inorganic phosphorus is one of the least available nutrients in soils of many terrestrial ecosystems (Vance et al. 2003). Low phosphorus availability activates a series of morphological, anatomical and physiological responses that maximize phosphorus acquisition (Raghothama 1999) and are directed to maintain internal phosphorus homeostasis (Ticconi and Abel 2004). Leaf growth depression under phosphorus deficiency is well documented (Radin and Eidenbock 1984, Chiera et al. 2002, Assuero et al. 2004, Kavanová et al. 2006). Ultimately, this growth reduction must be due to an alteration of cell division or cell elongation parameters. Plants suffering from phosphorus deficiency showed retarded growth (McMurtrey 1938, Alsaedi and Elprince 2000). The present investigation was undertaken to study the effect of phosphorus deficiency on anatomical structure in maize.

\section{Material and Methods}

Seeds of maize (Zea mays L. var. Barnali) were collected from Bangladesh Agricultural Research Institute (BARI), Joydebpur, Gazipur. Plants were grown in sand culture (Hewitt 1966) under phosphorus rich and phosphorus deficient modified half-strength Hoagland nutrient solution (Hoagland and Arnon 1950). Five plants were raised in each pot and there were ten pots for each treatment placed in randomized block design. The sand of control pots were moistened with $+\mathrm{P}$ nutrient solution twice in a week while that of phosphorus deficient pots with no phosphorus in the nutrient solution. Root ( $3 \mathrm{~cm}$ below sand surface), stem segments (fourth internode) and leaves (middle portion) were collected from 28-day-old maize plants. Transverse sections of the samples of $15 \mu \mathrm{m}$ thickness were done using a rotary microtome (OSK-9771, Japan). The sections were stained in safranin and fast-green, and having photographed (Nikon UFY-11A, Japan). For stomatal study, epidermal peels were taken from the upper surface of the leaves collected from fifth node of 28-day-old maize plants.

${ }^{1}$ Department of Botany, Ananda Mohan College, Mymensingh, Bangladesh. 


\section{Results and Discussion}

Effects on anatomy of root: In phosphorus deficient plants, epidermis layer became thick, exodermis also became thick walled and irregular in size compared to control (Fig. 1A, B). Adjoining to exodermis, a tissue of thick walled cells formed a distinct sclerenchymatous cylinder both in control (+P) and P-deficient plants. This cylinder was composed of $4-5$ layers of cells in P-deficient plant while in control it was composed of more thickened 10 - 12 layers of cells (Fig. 2A, B). Plant raised in absence of phosphorus presented 10 -12 cortical cell layers compared to 15 - 18 cell layers in control plant (Fig. 1C, D). The root of phosphorus-deficient plant showed thick walled endodermis and pericycle than that of control. Most of the lateral walls of the endodermal cells in P-deficient plants were also thicker than that of control (Fig. 1E and F). Lyon and Garcia (1944) reported that pericycle cells were thick walled and few in number due to phosphorus deficiency in tomato seedlings. In the root, significant structural changes due to phosphorus deficiency occurred in the vascular system. Under phosphorus deficiency treatment, vascular area was found to decrease and occupy less area with less number of xylem vessels having smaller cavity in the root (Fig. 1E, F). Liu et al. (2004) observed that phosphorus deficiency decreased number of xylem vessels with smaller area in the root of Vigna seedlings.
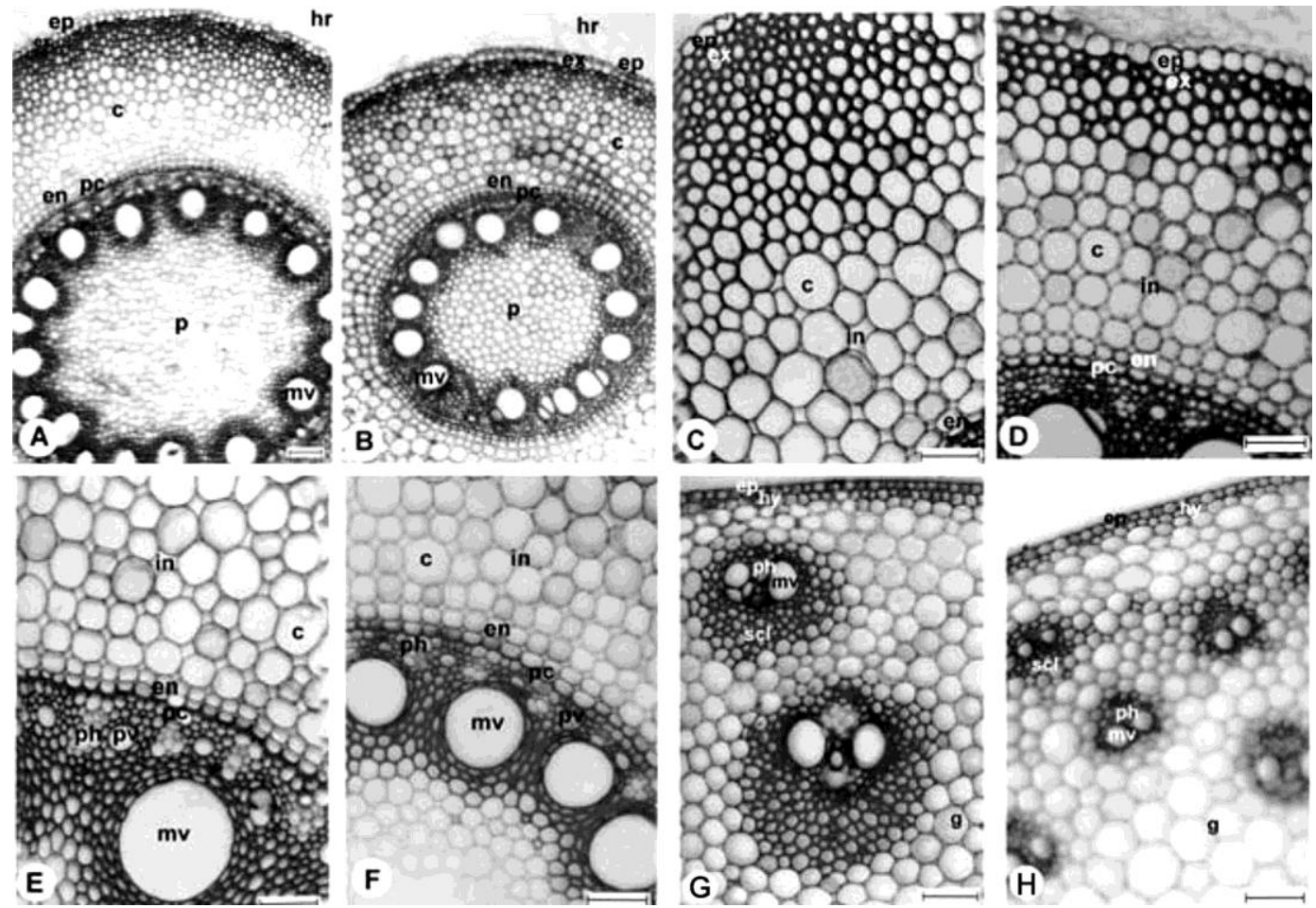

Fig. 1A-H: A-F. Transverse section of the middle part of the root of 28-day-old maize plant grown in sand culture with phosphorus (A,C,E) and without phosphorus (B,D,F). G-H. Transverse section of 4th internode of stem of 28-day-old maize plant grown under sand culture with $(\mathrm{G})$ and without phosphorus $(\mathrm{H}) . \mathrm{c}=$ cortex, en $=$ endodermis, ep $=$ epidermis, ex = cxodermis, $\mathrm{g}=$ ground tissue, $\mathrm{hr}=$ root hair, hy = hypodermis, in = intercellular space, $\mathrm{mv}=$ metaxylem, $\mathrm{p}=$ pith, $\mathrm{pc}=$ pericycle, $\mathrm{ph}=$ phloem, $\mathrm{pv}=$ protoxylem and $\mathrm{sc}=$ sclerenchyma cell. $\mathrm{Bars}=100 \mu \mathrm{m}$. 


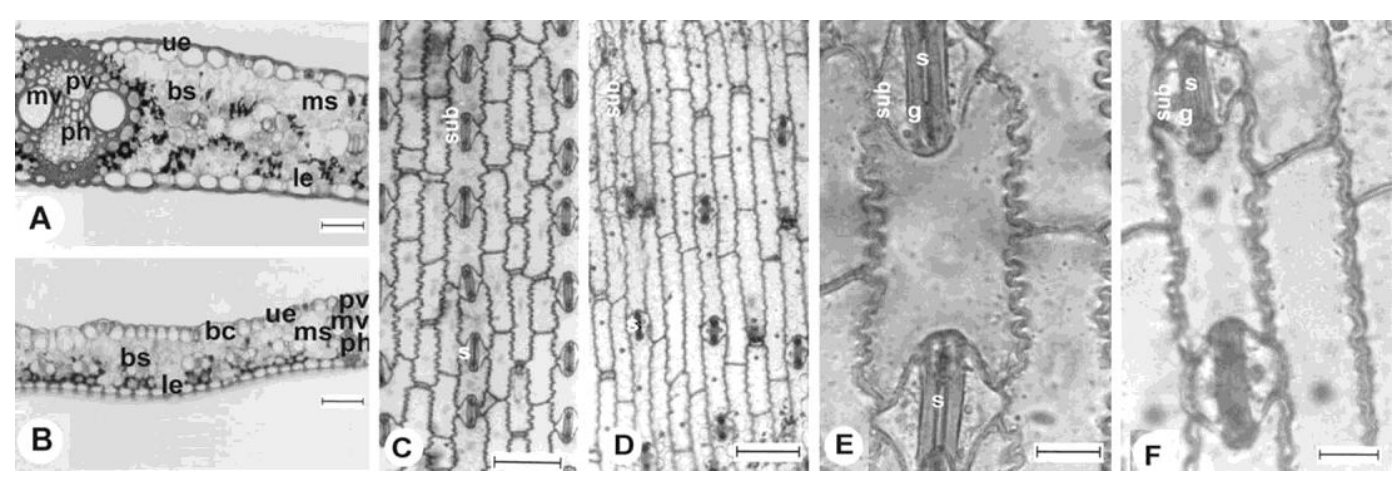

Fig. 2A-F: Leaf anatomy. A-B. Transverse section of seventh leaf of 28-day-old maize plant with (A) and without phosphorus (B). C-D. Peeling of maize leaf with (C) and without phosphorus (D). E-F. Close view of stomata with phosphorus (E) and without phosphorus (F). bc = bulliform cell, bs = bundle sheath, $\mathrm{g}=$ guard cell, le = lower epidermis, $\mathrm{ms}=$ mesophyll, $\mathrm{mv}=$ metaxylem vessel, $\mathrm{ph}=$ phloem, $\mathrm{pv}=$ protoxylem vessel, $\mathrm{s}=$ stomatal opening, sub $=$ subsidiary cell, $\mathrm{ue}=$ upper epidermis. Bars $=20 \mu \mathrm{m}$.

Effects on anatomy of stem: Phosphorus deficient maize plants showed a decrease in diameter of the stem. Similar results that decrease in diameter of the stem was also recorded in maize under phosphorus deficient condition (Lyon and Garcia 1944). Anghinoni and Barber (1980) observed that Zea mays grown under -P condition showed smaller root diameter. Phosphorus deficiency resulted in thickening of epidermal and hypodermal cells of the stem compared to that of control (Fig. 1G, H). The most significant changes occurred in the vascular bundles. In phosphorus deficient plant, vascular bundles became smaller in size and more or less uniformly distributed throughout the ground tissue. In control plant, the central part of the ground tissue possessed less number of vascular bundles. Under phosphorus deficiency, vascular bundles in the ground tissue were reduced in size with smaller size and cavity of the metaxylem vessels and size of phloem elements were also decreased as compared to that of control (Fig. 1G, H). The plant exposed to phosphorus deficiency had smaller thick walled cells in the central ground tissue than those of the plant grown under $+\mathrm{P}$ condition. Vasellati et al. (2001) observed a decrease in size of metaxylem vessels in the stem of Paspalum under drought condition. Lyon and Garcia (1944) noticed that tomato stem developed minimum phloem elements under P-deficient condition.

Effects on anatomy of leaf: Thickness of upper and lower epidermis as well as cell layers of mesophyll tissue and cell size decreased due to phosphorus deficiency (Fig. 2A, B). Phosphorus deficient leaf showed smaller vascular bundles with smaller size of the metaxylem vessel cavity. Phloem also occupied less area in phosphorus deficient plant compared to that of control. Chiera et al. (2002) showed that the cell size and thickness of epidermal cell was reduced under phosphorus deficient conditions in soybean leaf. In wheat leaf, phosphorus deficiency limited the leaf size by producing fewer cells of mesophyll tissue per leaf or limiting cell elongation (Daniel et al. 1998).

Effects on stomata of leaf: In phosphorus deficient leaf, number of stomata was decreased as compared to that of control (Fig. 2C, D). Phosphorus deficiency also resulted in smaller in size of stomatal opening. Guard and subsidiary cells also became reduced in size in phosphorus-deficient plant (Fig. 2E and F). Purohit (1995) reported that stomatal index, size of stomata and stomatal frequency in chickpea was decreased with increasing salinity. Nian et al. (2003) found that stomatal conductance and transpiration were decreased by phosphorus deficiency.

The phosphorus deficiency resulted in decrease in vascular area as well as decrease in size and number of stomata which may lead to decrease in growth and other morphological characters as well as yield of the maize plants. 


\section{References}

Alsaedi A.H. and A.M. Elprince. 2000. Critical phosphorus level for Salicornia growth. Agron. J. 92: 336345.

Anghinoni I. and S.A. Barber. 1980. Phosphorus influx and growth characteristics of corn roots as influenced by phosphorus supply. Agron. J. 72: 685-688.

Assuero S.G., A. Mollier and S. Pellerin. 2004.The decrease in growth of phosphorus-deficient maize leaves is related to a lower cell production. Plant Cell Environ. 27: 887-895.

Chiera J., J. Thomas and R. Rufty. 2002. Leaf initiation and development in soybean under phosphorus stress. J. Exp. Bot. 53: 473-481.

Daniel R., J.G. Wang, F.S. Zhang, J.Y. Cui, J.G. Wang and F.S. Zhang. 1998. Effect of phoglopite on plant growth under phosphorus deficiency. Commun. Soil Sci. Plant Analysis 34: 7-8.

Hewitt E.J. 1966. Sand and water culture methods used in the study of plant nutrition. $2^{\text {nd }}$ Ed. Agricultural Bureau, Farnham Royal, England. 547 pp.

Hoagland D.R. and D.I. Arnon. 1950. The water culture method for growing plants without soil. Circular 347, Univ. of Calif. Agric. Exp. Station, Berkeley.

Kavanová M.A.A. Grimoldi, F.A. Lattanzi and H. Schnyder. 2006. Phosphorus nutrition and mycorrhiza effects on grass leaf growth. P status- and size-mediated effects on growth zone kinematics. Plant Cell Environ. 29: 511-520.

Liu H.C., G.C. Chen, R.Y. Chen, Y.H. Kang and X.Y. Wu. 2004. Anatomical structures of seedlings of Vigna unguiculata ssp. sesquipedalis cultivars under phosphorus deficient stress. J. Plant Resources Environ. 13: 48-52.

Lyon C.B. and X. Liang. 1944. Anatomical response of tomato stems to variations in the micronutrient anion supply. Bot. Gaz. 104: 394-405.

McMurtrey J.E. 1938. Symptoms of field grown tobacco characteristic of the deficient supply of each of several essential chemical elements. US Dept. Agr. Tech. Bull. 612: 97-99.

Nian H., S.J. Ahn, Z.M. Yang and H. Matsumoto. 2003. Effect of phosphorus deficiency on aluminuminduced citrate exudation in soybean (Glycine max). Physiol. Plant. 117: 229-236.

Purohit S. 1995. Study of morphological changes associated with salt stress in chickpea (Cicer arietinum L.) variety C-235. M.Sc. Thesis, CCS Haryana Agril. Univ., Hissar.

Radin J.W. and M.P. Eidenbock. 1984. Hydraulic conductance as a factor limiting leaf expansion of phosphorus-deficient cotton plants. Plant Physiol. 75: 372-377

Raghothama K.G. 1999. Phosphate acquisition. Annu. Rev. Plant Physiol. 50: 665-693.

Ticconi C.A. and S. Abel. 2004. Short on phosphate: plant surveillance and countermeasures. Trends Plant Sci. 9: 548-555.

Vance C.P., C. Uhde-Stone and D.L. Allan. 2003. Phosphorus acquisition and use: critical adaptations by plants for securing a nonrenewable resource. New Phytol. 157: 423-447.

Vasellati V., M. Oesterheld, D. Medan and J. Loreti. 2001. Effects of flooding and drought on the anatomy of Paspalum dilatatum. Ann. Bot. 88: 355-360.

(Manuscript received on 8 August 2009; revised on 22 May 2010) 